\title{
SAARC and Region-building: Is South Asia a Region?
}

Bhumitra Chakra

\begin{abstract}
$\underline{\text { Abstract }}$
'Region' is a contested concept. Although scholars have extensively debated the issue, there is no consensus on the definition of region. While some scholars emphasise geographic proximity as a key factor, others put importance to cognitive and ideational factors, yet some others seek to combine the two perspectives to define region. Against such a background, this paper explains the complexities of defining South Asia as a region. It explores the historical evolution of the identification of the region and analyses how region building in recent decades, instead of consolidating its regionness, has produced a multiplicity of discourses, narratives and meanings about South Asia as a region. This is particularly evident if South Asia is examined in terms of 'economic', 'security' and 'cultural' region. Importantly, these discourses, narratives and meanings are not necessarily symmetrical and compatible with each other although they co-exist in an uneasy manner at both regional and national levels. And, they are contingent and subject to change over time.
\end{abstract}

Key words: Region, Regionalism, South Asia, SAARC, BIMSTEC, Security Complex

\section{Introduction}

Defining 'region' in International Relations (IR) is controversial (Mansfield \& Milner, 1999, p. 590). Some scholars emphasise geographical proximity while others give importance to the cognitive and ideational factors, yet a third group seeks to combine the two perspectives to define a region. Earlier studies on region and regionalism generally highlighted geographical proximity as an essential criterion of a region (i.e. Nye, 1971). Many scholars even today posit that 'a region is firmly rooted in territorial space: a group of people living in a geographically bounded community, controlling a certain set of natural resources, and united through a certain set of cultural values and common bonds of social order forged by history' (Hettne \& Soderbaum, 2000, p. 14). Regionness, these scholars argue, is 'the convergence of several dimensions' such as 'cultural affinity, political regimes, security arrangements and economic policies' which generates 'regional coherence within a particular geographic area' (Hettne et al, 2001, p. xxviii). The spatial factor is also considered important in contemporary studies on economic regionalism in which it is argued that economic regionalism primarily 
hinges 'on the importance of geographic proximity' (Mansfield \& Milner, 1999, p. 590). Hence, 'Geography', as a scholar has concluded, 'should not ... be dismissed outright as a starting point for identification of regions' (Fawn, 2009, p. 16).

Many scholars, however, find the essentialist, conventional view of defining a region primarily based on the 'geographic proximity' factor problematic because it presupposes an objective, static phenomenon which ignores the dynamics of social and political forces. Scholars belonging to the Constructivist school of thought, in particular, dismiss geographic proximity as a critical factor and define region in non-physical terms. They argue, countries sharing a communal identity comprise a region regardless of their location (Kupchan, 1997). According to Amitav Acharya, 'regions are not a geographic given, but are socially constructed, made and remade through interactions' (Acharya, 2012). Peter J. Katzenstein similarly maintains that regions" 'geographic designations are not "real", "natural" or "essential", they are socially constructed and politically contested and thus open to change' (Katzenstein, 1997, p. 7).

A third group of scholars seeks to combine the two perspectives and argues that members of a common region generally share cultural, economic, linguistic and political ties (Deutsch et al, 1957; Nye, 1971; Russett, 1967; Thompson, 1973)). Kym Anderson and Hege Norheim have noted that 'while there is no ideal definition [of a region], pragmatism would suggest basing the definition on the major continents and subdividing them somewhat according to a combination of cultural, language, religious, and stage-of-development criteria' (Anderson \& Norheim, 1993, p. 26). T.V. Paul also maintains that a region can be defined 'as a cluster of states that are proximate to each other and are interconnected in spatial, cultural and ideational terms in a significant and distinguishable manner' (Paul, 2012, p. 4). 
Keeping the above conceptual controversy into perspective, this paper investigates the intricacies of defining South Asia as a region. Apparently, there should not be a controversy over the regional definition of South Asia because it arguably can be defined in terms of the region's key institution - the South Asian Association for Regional Cooperation (SAARC) as all states in the subcontinent's geographical area are members of the organisation. A closer scrutiny, however, would reveal that defining South Asia as a region in the context of SAARC is not as simple as it may appear. Also, as will be illustrated in this paper, regionbuilding in recent decades through SAARC, instead of consolidating its regionness, has produced a multiplicity of discourses, narratives and meanings about South Asia as a region which has added new dimensions to the existing multiple ideas of the region. The complexities of defining South Asia as a region become particularly evident if it is viewed from the standpoint of 'economic', 'security' and 'cultural' region. Importantly, these discourses, narratives and meanings are not necessarily symmetrical and compatible with each other although they co-exist in a contradictory manner regionally and in national imaginations. And, they are contingent, fluid and subject to change over time.

The paper proceeds in the following manner. The next section explores the historical background to the rise of the term 'South Asia' to identify the region. Following it, the paper analyses the meanings of and discourses about South Asia as an 'economic region', 'security region' and 'cultural region' and illustrates how region-building through SAARC in the past decades has produced varied ideas of South Asia. Finally, key points of the paper's analysis will be summarised, and its general implications will be briefly noted.

\section{Historical Background}

The term 'South Asia' entered the regional lexicon only recently, particularly it got an official stamp by the establishment of SAARC in the 1980s. Historically the term 'India' or 
'the Indian subcontinent' was widely used primarily based on the idea of 'civilizational unity' and historical continuity although it encountered numerous contestations. The British colonial rule unified the erstwhile disparate areas of the subcontinent by spreading communication (road and rail links) which injected a sense of unity, but the colonial policy of 'divide and rule' gave rise to the 'politics of difference' which not only resulted in the partition of India in 1947 (on the partition, see Hudson, 1985; Tharoor, 2017), it also left legacies which continued to negatively affect the regional international relations, thus undermining the regional idea of South Asia.

The term 'South Asia' was first used outside the region and hence has an exogenous origin, courtesy of research centres that were established in US universities following the end of the Second World War, particularly in the 1960s (Cohen, 2006), and US State Department briefing documents on the region, i.e. The Subcontinent of South Asia of 1959 (MohammadArif, 2014). The term's exogeneous origin can also be located in Europe. For example, Germany’s Heidelberg University established the 'South Asia Institute' in 1962 (Ghosh, 2013, p. 103), although its mandate included all the countries of today's South and Southeast Asia, implying that it meant 'Southern Asia'. It was indeed consistent with the dominant narrative of the time in academic circles in which 'Southern Asia' covered both the regions of contemporary South and Southeast Asia (i.e. Brecher, 1963). International institutions, such as the UN, World Bank, Asian Development Bank etc., and American research centres also began to use the term 'South Asia' in their documents, but they defined the region in their own ways by lumping it with Central Asia, part of West Asia or Southeast Asia. It is evident that the meaning of South Asia in those usages was imprecise and these usages had no or negligible impact on the initiatives of region-building in later years. 
In terms of policy practices of the regional states, there was little indication of conceiving South Asia as a region before the late 1970s. Indeed, following the British withdrawal from the subcontinent, the thinking about regionalism/region building was geographically expansive encompassing the whole Asian continent privileging the ideology of panAsianism. Such an idea was particularly promoted by India. Even before the colonial rule formally came to an end, independent India's would-be prime minister, Jawaharlal Nehru, convened the first Asian Relations Conference in New Delhi from 23 March - 2 April 1947 in which cooperation among Asian nations was sought. The objectives of that conference were 'to bring together the leading men and women of Asia on a common platform to study the problems of common concern to the people of the continent, to focus attention on social, economic and cultural problems of the different countries of Asia, and to foster mutual contact and understanding' (Indian Council of World Affairs, 2017). At another Asian Relations Conference on Indonesia convened in January 1949 in New Delhi, a resolution called for the withdrawal of the Dutch forces from Indonesia and granting it complete independence. This call was made based on the spirit of Asian solidarity.

The issue of pan-Asian cooperation was also discussed at the Baguio Conference in the Philippines in May 1950 and then at the Colombo Powers Conference in April 1954. In 1955 at Bandung, Indonesia, an even larger Afro-Asian solidarity and policy coordination plan the Non-Aligned Movement (NAM) - was launched (Kahin, 1956). Those pan-Asian regional cooperation and integration schemes failed because (1) they were founded on "hope than reality' and (2) post-colonial realities soon began to surface and consequently moved the focus of the newly independent states from regional integration to national security and economic development (Sridharan, 2010, p. 293). Subsequently, region-building in Asia began to be developed along sub-regional lines, i.e. Southeast Asia, South Asia etc., as they 
appeared more manageable and viable, implying that region-building subsequently became more narrowly focussed.

The discussion in this section highlights that although the term 'South Asia' was used exogenously before the 1970s, its meaning was indeterminate and varied. Indeed, there was little clarity in the meaning of the term in geographical, ideational, emotional and interactive senses. And such usages probably did not have or had little impact, if any, in defining South Asia as a region in later years.

\section{SAARC, Region Building and Multiple Narratives of South Asia}

The first-generation Asian regionalism initiatives following the Second World War, as discussed above, failed, but they paved the way for the rise of more narrowly focussed regionalist projects in Asia. The establishment of the South Asian Association for Regional Cooperation in 1985 was such a regionalist project. ${ }^{1}$ It was the first formal region-building initiative in South Asia in which the term 'South Asia' became official and arguably emerged as the dominant term to define the region. Of course, by the time SAARC was formed, 'South Asia' was the only politically 'neutral' term which was acceptable to all regional states. Other competing terms, such as 'Indian subcontinent', 'Bharatbarsha' etc., were not acceptable to all countries because they were associated with the name of a state (India).

More than three decades have passed since the initiation of the regionalist project, how much clarity has emerged in defining the region of South Asia? As below analysis will highlight, the idea of South Asia remains as contested as ever and region-building in the past three decades has produced even more competing narratives and discourses about the region.

Apparently, SAARC appears to be an impressive regional organisation in terms of the identified areas of cooperation, but it has failed to implement most of them which has 
generated the view amongst scholars that SAARC's achievements are mostly 'on paper' (Dash, 1996, p. 188). While the smaller members of SAARC generally have been enthusiastic about the activities of the organisation, India and Pakistan have shown varying degrees of interest in the regionalist project. Indeed, the clashing interests of the latter two states have primarily hindered the progress of SAARC. Currently, the organisation has reached a stalemate and its latest summit meeting scheduled for November 2016 in Islamabad, Pakistan's capital, had to be postponed due to a hostile relationship between the two most powerful members of the group - India and Pakistan (The Express Tribune, 2016).

There are many reasons behind SAARC's failure to pull the regional states together to build a common region. It is beyond the scope of this paper to provide an analysis of those factors; however, one factor should be noted here because of its implications for the below analysis. A key structural barrier to successful regionalism in South Asia is the asymmetric nature of the regional system. India's geographic size, economic strength, resource endowment, and military might, which are larger than those of the other South Asian states combined, make South Asia an essentially Indo-centric region (Kodikara, 1983). Also, the country is centrally located in the region with land border with most South Asian states (except the two Island nations - Sri Lanka and Maldives and Afghanistan, which joined SAARC only in 2007) and no two original SAARC members share land border with each other. Such structural power asymmetry inhibited regional cooperation. Thomas Thornton argues that in regional organizations it is difficult for "countries to establish balanced relations when one has a significant advantage in power over the other states (Thornton, 1991, p. 135).

The lack of progress in the regionalist project implies that the member states have failed to harmonise their competing visions and discourses about the region. More to it the SAARC process has added new dimensions to the pre-existing multiple discourses and narratives. 
These discourses and narratives become more evident if we discuss the ideas of South Asia in terms of economic, security and cultural region. The below analysis presents greater details of those competing discourses. Importantly, these regional discourses have varied narratives and meanings which are asymmetrical, incompatible and even opposed to each other although they co-exist oddly at both national and regional level. Also, these narratives and meanings are contingent and have changed over time.

\section{Economic Region}

South Asian states have contrasting ideas about economic region. SAARC could not pull them to a common narrative in the past three decades; indeed, the SAARC process has generated multiple discourses and interpretations about it.

Even before the rise of SAARC, South Asian states had contrasting economic outlooks and ideas about economic region. India pursued a policy of mixed-economy from the country's independence to the early 1990s (on the evolution of India's economic policy, see Frankel, 2006). During this period, New Delhi adopted import-substitution as a key plank of its economic growth policy and strived to achieve economic self-sufficiency. By pursuing such an economic policy, India indeed followed a policy of protectionism and deregionalisation (Mohan, 2017).

Pakistan also pursued an import substitution policy before the formation of SAARC, but compared to India it was more outward-looking than seeking economic self-sufficiency. Since its emergence as an independent state in 1947, Pakistan has been an economy of 'boom and bust' (Murtaza, 2017; Rashid, 2017). The 'yo-yo' economy, as Akbar Zaidi puts it, has evolved in a way in which at times the economy grew at a spectacular pace while frequently plunging into economic downturn and crisis (Zaidi, 2014). Consistent with such a character of the economy, Pakistan's discourse about economic region has fluctuated over the decades. 
Traditionally, Pakistan has looked beyond the region for economic growth, particularly toward the USA, China and the Middle East. Instead of cultivating regional economic linkages and intensifying economic interactions with the regional states, the country has sought economic opportunities beyond the region.

Smaller states of the region pursued varied economic policies from socialist-oriented mixed economy to import substitution and economic autarky before the establishment of SAARC. They were mostly dependent on external economic aid and were considerably outwardlooking instead of seeking trade and economic relationships with regional states.

The reactions from the regional states to Bangladesh's proposal for a regional organisation also highlight their contrasting perspectives about South Asia as an economic region. Although smaller states of the region enthusiastically supported Bangladesh's regional grouping proposal, the reactions from New Delhi and Islamabad were lukewarm, hesitant and cautious. Both of course eventually joined the organisation. India joined it because 'it did not want to be isolated further in the region' (Mohanan, 1992, p. 5). Pakistan also joined the organisation because it feared that if it did not do so, 'it could be left out of the arrangement and become isolated in the region' (Bokhari, 1985, p. 374). Both the states, however, remained cautious about their support to the activities of the organisation while the smaller states extended their wholehearted support to SAARC.

Initially many Indians viewed SAARC as an unnecessary organisation for their country. Dixit claims that some people in India viewed that their country 'does not need Subcontinental regionalism because by itself it incorporates much of South Asia by economic strength, geopolitical prowess and miscellany' (Dixit, 2013, p. 32). Partha Ghosh, a noted Indian scholar on regional affairs, has concluded that South Asia as a region is 'on the periphery of India's consciousness' (Ghosh, 2016). Indian policy elites have traditionally viewed that 
SAARC could not offer the economic opportunities that India had been looking for (Muni \& Jetly, 2010, p. 25), so New Delhi should not restrict itself to South Asia and must look beyond it by expanding the regional idea through connectivity, trade and investment to realise its ambition to be a global power. It implies that New Delhi essentially neglected economic regionalism in the formative years of SAARC.

India abandoned its pre-1990s economic growth model when the country faced a serious balance of payment crisis in 1991. The crisis forced New Delhi to undertake economic reforms. Consequently, New Delhi adopted an export-led economic growth model and opened the Indian economy for foreign business. ${ }^{2}$ From that time onward, India embraced globalisation and integrated its economy to the global economy. Consistent with this trend, India's economic outlook and its idea of economic region changed in the 1990s from what it was in the 1980s which essentially sought to reverse the earlier policy of 'deregionalisation' and the idea of 'India equals South Asia'. While India embraced economic regionalism, it added new layers into it, thus moving to an idea of what might be called 'layered economic region'. In this idea while it sought to reap the economic (and other) benefits of regionalism, simultaneously it expanded the regional idea to realise its economic, political and strategic objectives.

By contrast, Islamabad's strategy remained the same in which it was hesitant to deepen regional economic integration. The key reason for this is that politico-strategic calculations guided the country's approach toward SAARC notwithstanding the fact that the country could gain significant economic benefits from regional economic cooperation (Ahmed et al, 2010). It is arguable that Pakistan has been a reluctant region builder and indeed a positive discourse on economic region is hardly visible in Pakistan's policy approach toward the regional organisation. 
The contrasting economic regional visions also became apparent when SAARC moved from functional issues to cooperation in substantive economic areas. In 1993, the SAARC Preferential Trading Arrangement (SAPTA) agreement was concluded which aimed to promote intra-SAARC trade. The agreement was viewed as a 'significant achievement' of the organisation (Saez, 2011, p. 66). Then, in another bold economic cooperation initiative, the South Asian Free Trade Area (SAFTA) agreement was signed in 2004, which aimed to create a regional free trade area by 2016 (which was not achieved due to a hostile relationship between India and Pakistan). While smaller states wholeheartedly supported the two initiatives, India and Pakistan could not extend full cooperation due to their strategic rivalry. It should, however, be noted that New Delhi was more supportive to the two initiatives while Islamabad could not extend full support due to its concern that they would lead to greater Indian influence in the region.

The SAARC Motor Vehicle agreement at the $18^{\text {th }}$ summit in 2014 in Kathmandu provides another example about contrasting economic regional visions of the South Asian states. The document was ready for signature at the summit, but right before the signing of the agreement Islamabad withdrew its support, thus scuttling the initiative. It meant that Islamabad's economic region building was less important than its strategic anxiety relative to India.

New Delhi's changed thinking about economic regionalism was further reflected when it promoted the idea of 'Growth Tringle' within SAARC. Borrowing from ASEAN, the idea was adopted at the 1997 Male SAARC summit, which paved the way for the creation of Bangladesh, Bhutan, India and Nepal (BBIN) 'Growth Quadrangle' in the eastern part of South Asia (Kumar, 2007). This was an interesting addition to India's concept of economic regionalism. 
New Delhi's regional economic discourse from the early 1990s was influenced by the imperative of globalisation and the need to expand the economic regional idea beyond its immediate neighbourhood. The expanded regional idea was clearly reflected in the adoption of the policy of 'Look East' (later 'Act East') $)^{3}$ which aimed to build connectivity, trade and investment relationships with the countries of East and Southeast Asia. Also, India's participation in the 'Bay of Bengal Initiative for Multi-Sectoral Technical and Economic Cooperation' (BIMSTEC), a cross-regional initiative comprising Bangladesh, Bhutan, India, Myanmar, Nepal, Sri Lanka, and Thailand, further manifested New Delhi's shifting discourse on economic region (Kundu, 2017). The BIMSTEC has now effectively replaced SAARC as New Delhi's institution of preference for regional cooperation. India's foreign secretary has stated that SAARC is a jammed institution, so priority should be given to BIMSTEC (Times of India ,2017). This was evident at the Goa BRICS summit in October 2016 when New Delhi invited BIMSTEC heads of state/government, instead of SAARC leaders, to attend the outreach event. It also reflected current thinking in New Delhi about regionalism in which SAARC is deprioritised and other institutions are promoted which do not include Pakistan.

Similarly, two other initiatives highlighted India's changing idea of economic region. The first was the cross-regional Kunming initiative (transformed into BCIM or 'Bangladesh, China, India and Myanmar' group) of 1999 which initially was conceived as a nongovernmental initiative but later the governments of the four countries endorsed it to promote greater connectivity, trade and investment (Singh \& Cuiping, 2017). It should, however, be noted that the BCIM was principally pushed by China while New Delhi remained a cautious participant. The second was the 'South Asia Subregional Economic Cooperation (SASEC) comprising Bangladesh, Bhutan, India, Maldives, Myanmar, Nepal and Sri Lanka which was created in 2001. It aimed to broaden economic integration in the eastern part of South Asia 
which was thought to be more effective than SAARC because the group did not include Pakistan.

New Delhi has also taken significant steps to expand its idea of economic region to its West. India's 'Look West' policy represents such a trend in its evolving idea of economic region. In recent years, India has employed significant diplomatic capital to build its West Asia engagement (Baru, 2016; Teckchandani, 2016). New Delhi has not only consistently worked to build its economic relations with the Middle Eastern states, it also has sought deeper economic relations with Afghanistan and Central Asian states via Iran. India's investment to build the Iranian Chabahar port symbolises this trend in India's policy (Chandran, 2017).

In recent years, Pakistan has drifted even further outward instead of its own region. Islamabad has now firmly put its economic future in its economic relationship with China. Pakistan signed a free trade agreement with China in 2006 and then initiated a $\$ 56$ billion investment initiative known as the China-Pakistan Economic Corridor (CPEC) in 2015, which was a part of China's Belt and Road Initiative. Pakistanis believe that the CPEC will bring economic prosperity to their country. ${ }^{4}$ Islamabad is also striving to build economic ties with the Central Asian states as energy sources and export market.

Although smaller states generally have been enthusiastic supporter of SAARC, in recent years there have been modifications in their outlooks as SAARC failed to deliver tangible economic benefit and as the organisation remained hostage to the Indo-Pakistani rivalry. The initial narrative on economic regionalism got modified in later years as smaller states (except Maldives and Afghanistan) began to pursue alternative forms of economic regionalism as can be evidenced in the formation of BBIN, BIMSTEC SASEC and BCIM. Two diversions occurred here from the original idea of regionalism conceived in SAARC. The first is the rise of sub-regionalism in the form of 'Growth Quadrangle' (BBIN) in the eastern part of South 
Asia. The second is the rise of cross-regional economic regionalism manifested in the formation of BIMSTEC and BCIM. With these, the idea of South Asia as an economic region diluted from what was originally conceived in SAARC.

The above discussion highlights multiple, contrasting and evolving narratives about economic region of the South Asian states. India's idea of economic region has multiple narratives and meanings that are manifested in its discourses on SAARC, 'Growth Quadrangle', 'Act East' policy, 'Look West' policy and cross-regional cooperation (BIMSTEC, SASEC and BCIM). These narratives and meanings of South Asia as an economic region are fluid, indeterminate and overlapping ranging from viewing itself as coterminous to the region to expanding the economic region to its east and west, and even to the global level. The narratives have transformed over the years and gradually there has emerged an idea of 'layered economic region' in its discourses.

Pakistan is not only a reluctant economic region builder, it does not have a coherent idea about economic region. For one thing, Pakistan is ambivalent about its regional identity which is evident in its contradictory claims of being a South Asian, West Asian or a Central Asian power at different historical junctures (Zaidi, 2009). Consequently, Pakistan never had a coherent, consistent idea about economic region and its discourses on economic region manifest multiple narratives and meanings. Pakistan traditionally has looked beyond South Asia to build economic connections instead of seeking closer economic ties with the SAARC countries.

The smaller states are the keen economic region builders and enthusiastic supporters of SAARC. As the economic region-building through SAARC stalled, their outlooks and ideas also underwent changes in which they sought sub-regional economic cooperation within South Asia and cross-regional economic ties with East and Southeast Asia. 
To summarise, SAARC could be the primary vehicle to build South Asian economic region and other ideas could be integrated within the core idea, but that did not happen. Instead, multiple ideas and discourses on economic regionalism have flourished in contemporary South Asia.

\section{Security Region}

The discourses and narratives about South Asia as a 'security region' are also varied. Three decades of regionalism could not bring any coherence in the security outlooks and discourses of the regional states. The region's status as a security region has remained as contested as ever.

As discussed above, South Asia is an Indo-centric region. India's regional security discourse is built on the perception of its pre-eminence in South Asia. New Delhi equates India's security with the region's security and views the regional states as its legitimate security sphere. India inherited such a security framework from the British Raj in which the idea of the control of the Indian landmass and the Indian Ocean was emphasised (Kavic, 1967).

The British Raj's strategic framework was adopted by independent India which came to be known as 'India Doctrine'. The doctrine stipulates that India has no intention of intervening in the internal affairs of its neighbouring states, but if any South Asian country needs external security assistance, it should ask from India and no one else; a failure to do so is to be considered 'anti-Indian' (Gupta, 1983, p. 20). New Delhi operationalised its regional security doctrine at least on three occasions in the 1980s; in 1987 it undertook a peacekeeping operation in Sri Lanka in an attempt to resolve the ethno-national conflict in the island state (although it failed); in 1988 it extended rapid military assistance to Maldives at the request of Male; and in 1989-90 it imposed an economic blockade on landlocked Nepal as the latter attempted to build closer strategic relations with China (Hagerty, 1991). 
The regional states strongly resent India's regional security doctrine. They are concerned about India's strategic motivations and the impact of power asymmetry on their status as sovereign political entities (Chakma, 2009). Such concerns accentuated further following the merger of erstwhile independent Sikkim with the Indian Union in 1975. India's neighbours have responded by adopting various strategies ranging from coming closer to India (bandwagoning) to building a cooperative security structure through SAARC to different forms of power balancing.

Pakistanis view that India is the key source of regional insecurity and the chief threat to Pakistan's survival as a state. Since 1947, Pakistan has consistently maintained such a security discourse. To counter the perceived India threat, Pakistan employs a balance of power strategy (Chakma, 2009). While it has stridently strived to maintain a military power balance, which has led it even to build nuclear weapons (Chakma 2002), it has traditionally looked outward for military assistance, notably from the USA (during the Cold War) and China (particularly in the post-Cold War era). ${ }^{5}$ In the 1950s, Pakistan became member of the US-sponsored alliance systems - SEATO and CENTO. During the Cold War period, Pakistan relied on the US to augment its military power ('offshore balancing'; Rudolph \& Rudolph, 2006). From the 1960s onward, Pakistan also cultivated closer relationship with China which became even closer after the end of the Cold War turning it into what Pakistanis call a 'all weather friendship' (on Pakistan-China relations, see Ali, 2017; Small, 2015).

The opposing security discourses and policies of India and Pakistan have produced a complicated regional 'security complex' (on this, see Buzan \& Rizvi, 1986; Buzan, 2011). ${ }^{6}$ Their opposing security policies and strategic rivalry not only reflect their different visions of South Asia as a security region, they also have affected SAARC's progress. 
Two narratives are apparent in the discourses of small SAARC members about security. First, they view that SAARC would help to overcome their security predicament vis-à-vis India and Pakistan (contextualising Afghanistan) and consolidate their political sovereignty by creating a cooperative security structure. This is a key reason, in addition to expectation of economic benefits, why smaller states wholeheartedly supported SAARC from the beginning. This perception of the smaller states can be contrasted with the perceptions of the two big member states of SAARC. Contradictory to the first, the second narrative is that they need to pursue a policy of power balancing by fostering better relations with extra-regional big powers to countervail Indian and Pakistani power and safeguard their political sovereignty (Chakma, 2009). Of course, Bhutan's policy can be contrasted in this context, and it seems that Thimpu follows a 'bandwagoning' strategy by coming closer to India. Put simply, there are different discourses and narratives in the smaller SAARC countries about South Asia as a security region.

The 'China factor' constitutes a contradiction in India's regional security discourse. Although New Delhi 's regional security doctrine is built on land and ocean control as if to demarcate the boundary of South Asia as a 'security region', its strategic planning has always included China as if it is part of South Asia's security zone. For example, a key rationale for building nuclear weapons by India was the 'China factor' and its strategic planning has invariably factored China (Chakma, 2004). Therefore, Indian narratives highlight multiple, even contradictory, meanings of South Asia as a security region.

Pakistan advocates China's membership in SAARC (which India opposes). Islamabad's intention here is that if China becomes a member of SAARC it will give an advantage to Pakistan in its security rivalry with India. 
The above discussion highlights contrasting ideas and narratives about South Asia as a security region. India's security discourse has multiple narratives, but it is informed by realist orientation in which power approach to security is dominant. This framework is contradictory to the vision of a security region conceived in SAARC. Pakistan's security policy is also realist-oriented, but it is primarily based on the idea of countering Indian power. Similar to India, Pakistan's security approach is also contradictory to the idea of SAARC. The security vision of SAARC is reflected in the perceptions of the smaller states, yet contradicting this position, some of them seek closer ties with external big powers in order to neutralise the impact of Indian and Pakistani power on their sovereignty.

\section{Cultural Region}

The discourses on culture, identity and belongingness in the South Asian states present contested narratives about South Asia as a cultural region. While India emphasises the existence of a subcontinental cultural unity underpinned by civilizational and historical continuity, others emphasise the 'politics of difference' to demonstrate their distinct identity relative to India. This has to do with the politics of 'nation-building' in the age of 'nationstate' in the post-colonial subcontinent. Sudipta Kaviraj maintains that state formation in India, Pakistan and Bangladesh make it difficult 'to think of South Asia as a space of emotional inhabitance' (Kaviraj, 2014). As illustrated below, India and other states present contrasting narratives and meanings about South Asia as a cultural region.

In the Indian view, the subcontinental culture is indivisible and unique which is underpinned by civilizational and historical continuity. Notwithstanding the diversity of cultures, the dominant Indian narrative is that there is a coherence and unity in them ('unity in diversity'). 
more about an idea ... which includes multitude of languages and culture that we celebrate as a whole, like a bouquet of colourful flowers' (Indian Express, 2017).

In support of the Indian narrative, numerous examples can be cited to highlight the existence of a well-connected subcontinental cultural structure. Hindi, Bengali, Nepali, Pashtu, Punjabi, Sindhi, Tamil, and Urdu are widely spoken in at least two countries of the region. Music and dance-forms are a shared heritage of all the communities of the region and have region-wide appeal. Bollywood films are popular throughout the region irrespective of national boundaries as well as among the diaspora South Asian population throughout the world which produces a sense of 'community' (Mohammed-Arif, 2014). Pakistani films and dramas are popular in some parts of India. Bengali films and dramas are reciprocally popular on both sides of Bengal. Nepali films, dramas and music are popular in parts of India and Bhutan. Therefore, cultural connections are well-established among communities irrespective of national boundaries, implying that there is an overarching subcontinental culture in South Asia. SAARC meant to reinforce and strengthen this cultural structure and create a sense of community in the region.

But the Indian narrative of 'one civilisation' or 'shared history' is contested by others. The 1947 partition, the breakup of Pakistan in 1971 and in general the arrival of the 'nation-state' are manifestations of contestations to the Indian cultural narrative. The 'politics of difference' pursued by Pakistan and Bangladesh essentially means opposition to the Indian narrative of civilizational unity of the subcontinent and its historical continuity. Therefore, it is arguable that the idea of cultural unity in South Asia is hugely contested.

Pakistan, as noted above, has an identity problem; indeed, it is 'confused about its identity' (Hyat, 2017). The country's identity problem has several dimensions and many reasons, but it primarily derives from the interplay of two contradictory forces: (1) there is an overarching 
subcontinental culture which Pakistan cannot disown; (2) following its emergence as an independent state it needed to build a distinct identity which would differentiate it from India. The latter led it to pursue 'politics of difference' in search of a 'national identity'.

The Pakistani dilemma about identity goes back to its origin as an independent state in 1947. As it was carved out as a homeland for the Indian Muslims, it needed to build an identity for the new nation. But Pakistanis were not certain about what kind of 'identity' they should construct. Some argued to base it on the religion while others preferred a secular identity. After seven decades, Pakistanis have yet to resolve this dilemma. Another dimension of the Pakistani identity dilemma, as noted above, is that while it needed to build a distinct cultural identity as a nation-state relative to India, Pakistanis found it challenging because of the existence of an overarching subcontinental culture. The region-wide shared cultural production occurs daily by various means, particularly through film, music, dance etc. Urdu, the national language of Pakistan, originated in Uttar Pradesh which is now in India. Indeed, Urdu and Hindi are, as a researcher posits, one language (Hasan, 2017). So, the cultural connections among the modern South Asian states are real and it is difficult to disentangle the Pakistani culture from the overarching regional culture.

Pakistan's strategic rivalry with India intensifies its identity problem. Owing to this factor, Pakistan at times has identified itself with West Asia and other times with Central Asia. After eastern wing seceded to become independent Bangladesh in 1971, Pakistan began to identity itself more with the Middle East and began to cultivate greater ties with the countries of that region deliberately downgrading its links with South Asia. Zulfiqar Ali Bhutto in the 1970s felt 'the need for Pakistan to develop closer links with the Islamic world and to look towards the Middle East rather than elsewhere in Asia' (Talbot, 1998, p. 235). Indeed, the Pakistani 
ambivalence about its identity and regional belongingness is set to continue in the future, implying the continuity of contestation over South Asia's cultural regionness.

The smaller states of the region have a similar identity dilemma like that of Pakistan relating to the cultural region of South Asia although the manifestations of that dilemma are different in those countries. While the smaller states of South Asia acknowledge the existence of cultural connections across the region, they prioritise and promote their own cultural identities to consolidate their sovereignty vis-à-vis India.

The emergence of independent Bangladesh ('another partition') is interesting in the context of South Asia as a cultural region. While the creation of Pakistan in 1947 represented a 'civilizational' identity for the 'Indian Muslims', Bangladesh's emergence as an independent state disrupted that narrative, thus moving the new country toward a new 'national cultural narrative'. Interestingly, the narrative was constructed to support 'nation-building' which primarily aimed to consolidate the political sovereignty of the state.

The cultural identity contestations are set to continue in South Asia in the foreseeable future as part of the politics of 'nation-state' systems. A vibrant SAARC can reduce the degree of contestations, yet the region's nation-states will continue to build their own cultural identity as a strategy of strengthening their sovereignty.

\section{Conclusion}

This paper has explored the complexities of defining South Asia as a region. It has illustrated how SAARC has not only failed to bring any clarity in South Asia's regional definition, it also has added new dimensions to the existing multiple ideas of South Asia.

The term 'South Asia' as a regional category was first used exogenously in America and Europe. In South Asia, the term firmly entered the official lexicon by the formation of 
SAARC in the 1980s. Before the rise of SAARC, regionalism in Asia was general and encompassed the whole Asian continent. In various efforts of pan-Asian regionalism, India played a key role. But they were largely unsuccessful due to a variety of reasons, in particular because of a lack of clarity of purpose of those initiatives. Subsequently, regionalism emerged based on narrowly-focussed areas; SAARC emerged against such a backdrop in the 1980s.

It was hoped that region-building through SAARC would bring clarity in South Asia's regional definition. As the analysis of this paper has highlighted, this has not happened, instead new dimensions, as noted above, have been added to the already existing multiple ideas of South Asia. The narratives and meanings of region vary from country to country and even within a state. These discourses and narratives become clear if South Asia is explained in terms of 'economic', 'security' and 'cultural' region. The South Asian states have different understandings of the region along these lines. Also, national narratives about the region, as analysed in this paper, are incompatible with each other and they have evolved over time. For example, Indian understanding of South Asia as an 'economic region' has moved from one discourse to another as reflected in its SAARC, sub-regional, trans-regional economic cooperation policies, which I have termed as an idea of 'layered economic region'. These Indian discourses are incompatible with those of the Pakistani narratives as reflected in its West Asia and CPEC policies. In terms of 'security region', the Indian discourse is completely at odds with other states of the region. South Asia as a 'cultural region' also presents similar incompatibility in regional discourses as explained in the paper. Put simply, there is no common narrative and meaning of the region in the discourses of the South Asian states. 
It is interesting to contrast South Asian regional definition dilemmas with other regions such as Europe and Southeast Asia. These regions also have dilemmas of defining their regions along the lines that have been illustrated in this paper but they have overcome to those dilemmas to a large degree by building successful regional cooperation. For example, Southeast Asian states had opposing security policies and had territorial disputes before the establishment of ASEAN, but no one raises them today because of maintaining ASEAN solidarity.

The analysis of this paper has implications for the debate about regional definition. As illustrated at the beginning of the paper, there are three conceptual positions about the definition of region: (i) an essentialist position in which geographic proximity (space) is emphasised and a region or a regional grouping is conceived as a natural entity; (ii) a nonphysical definition in which it is conceived that regions are made and unmade by interactions; (iii) a third definition seeks to combine the two perspectives. The first perspective is problematic because the countries of eastern South Asia extended the economic region by creating BIMSTEC, BCIM, BBIN and SASEC which included China (BCIM), Myanmar (BIMSTEC and BCIM) and Thailand (BIMSTEC). Furthermore, the inclusion of Afghanistan as SAARC's eighth member in 2007 and the discussion of China becoming a member of SAARC in the 1990s made geographic limit of the region changeable.

The analysis of this paper to some extent supports the arguments of the second conceptual perspective in the sense that regions are made and unmade by the dynamics and patterns of interactions. But, as analysed in this paper, SAARC has failed to build a common region notwithstanding its existence for over three decades. The analysis of this paper highlights that the ideas and discourses of the region evolved over time, thus highlighting the contingent nature of regional definition and fluid meanings of discourses. 
The third perspective is also problematic, primarily on the spatial ground and the peculiar realities of South Asia's region-building experience. The inclusion of new members (i.e. China) in SAARC will see a geographically expanded region which will add new complexities in the organisation. Put simply, South Asia is too complex to be clearly defined as a region.

\section{ENDNOTES}

\footnotetext{
${ }^{1}$ Bangladesh took the initiative to establish 'institutional arrangement' for regional cooperation. In the late 1970s, it began discussions with the South Asian states for a regional grouping and the president of Bangladesh formally wrote to his South Asian counterparts in May 1980 for a 'ASEAN-like' regional organisation (Mishra, 1982, p. 213) which culminated into the formal launching of SAARC in December 1985 (on the origins of SAARC, see Muni \& Muni, 1984; Gupta, 1986; Ahmed, 1985).

${ }^{2}$ Although the 1991 economic reforms are conceived to be the consequence of the balance of payment crisis, the change was gradually taking shape in the 1980s (Kohli, 2006a; Kohli, 2006b).

${ }^{3}$ During the time of previous UPA government, the policy was dubbed as 'Look East' which was rephrased as 'Act East' when the NDA government took over power in 2014. It was done to prioritise the country's engagement with East and Southeast Asian countries (Rajendram, 2014); Kaul \& Chakraborty, 2016).
}

${ }^{4}$ Reports and op ed pieces in the Pakistani newspapers manifest such an expectation (Awan, 2017). Of course, there are opposing views as well regarding the extent of benefit from the CPEC (Kardar, 2017; Dawn, 2017).

${ }^{5}$ Not only Pakistan, India also aligned with the Soviet Union during the Cold War era to augment its diplomatic and military power. South Asia thus turned into an intrusive system in which foreign powers intruded into the region's international relations (Brecher, 1963). It is noteworthy that it went against India's regional security doctrine, thus contradicting and complicating India's discourse on South Asia as a security region.

${ }^{6}$ Although India-Pakistan strategic rivalry has primarily shaped the structure of the South Asian security complex, the intrusion of extra-regional powers has greatly influenced the security relationship of the two states and the structure of the region's security complex (Rynning, 2017). While China historically has been a significant factor, in recent years, China's footprint has increased in South Asia as a security actor, thus affecting the regional security complex.

\section{REFERENCES}

Acharya, A. (2012). Comparative Regionalism: A Field Whose Time Has Come? The International Spectator, 47(1), doi.org/10.1080/03932729.2012.655004

Ahmed, E. (1985). SARC: Seeds of Harmony. Dhaka: University Press Ltd 
Ahmed, S., Kalegama, S., \& Ghani, E. (Eds.) (2010). Promoting Economic Cooperation in South Asia: Beyond SAFTA. New Delhi: Sage Publications.

Ali, G. (2017). China-Pakistan Relations: A Historical Analysis. Karachi: Oxford University Press.

Anderson, K., \& Norheim, H. (1993). History, Geography, and Regional Economic Integration. In K. Anderson \& R. Blackhurst (Eds.). Regional Integration and the Global Trading System. London: Harvester Wheatsheaf.

Awan, Z. A. (2017, June 16). Understanding the China-Pakistan Economic Corridor. The Express Tribune. Retrieved from https://tribune.com.pk/story/1436563/understandingchina-pakistan-economic-corridor/

Baru, S. (2016, March 29). The Sprouting of the 'Look West' Policy. The Hindu. Retrieved from http://www.thehindu.com/opinion/lead/sanjaya-baru-writes-the-sprouting-ofthe-look-west-policy/article7554403.ece

Bokhari, I. H (1985). South Asian Regional Co-operation: Progress, Problems, Potentials, and Prospects. Asian Survey, 25(4), 371-390.

Brecher, M. (1963). International Relations and Asian Studies: The Subordinate State System of Southern Asia. World Politics, 15(2), 213-235.

Buzan, B. (2011). The South Asian Security Complex in a Decentring World Order: Reconsidering Region and Power Ten Years On. International Studies, 48(1), 1-19.

Buzan, B. \& Rizvi, G. (1986). South Asian Insecurity and the Great Powers. London: Palgrave Macmillan.

Chakma, B. (2009). South Asia's Realist Fascination and the Alternatives. Contemporary Security Policy, 30(3), 395-420.

Chakma, B. (2004). Strategic Dynamics and Nuclear Weapons Proliferation in South Asia. Bern: Peter Lang.

Chakma, B. (2002). Road to Chagai: Pakistan's Nuclear Programme, Its Sources and Motivations. Modern Asian Studies, 36(4), 871-912.

Chandran, D.S. (2017, October 31). India and Kabul play new round in Great Game: Chabahar. The Indian Express. Retrieved from http://indianexpress.com/article/india/india-kabul-play-new-round-in-great-gamechabahar-port-iran-pakistan-afghanistan-4914847/

Cohen, B. (2006). The Study of Indian History in the US Academy. India Review, 5(1), 144172.

Dash, K. (1996). The Political Economy of Regional Cooperation in South Asia. Pacific Affairs, 69(2), 185-209.

Dawn (2017, August 2). One-way street: CPEC more about expanding China's growth than benefit for Pakistan. Retrieved from https://www.dawn.com/news/1349148

Deutsch, K. W. et al (1857). Political Community and the North Atlantic Area: International Organization in the Light of Historical Experience. Princeton, N.J.: Princeton University Press. 
Dixit, K. M. (2013). Federalism on the Road: Region and Regionalism. In A. Najam \& M. Yusuf (EDS.) South Asia 2060: Envisioning Regional Futures. London: Anthem Press.

Fawn, R. (2009). 'Regions' and their study: wherefrom, what for and whereto. Review of International Studies, 35(S1), 5-34, https://doi.org/10.1017/S0260210509008419

Frankel, F. R. (2006). India's Political Economy: The Gradual Revolution. New Delhi: Oxford University Press.

Ghosh, P. S. (2016). Region without Regionalism: Cooperation in South Asia. Economic and Political Weekly, 51(32), 114-121.

Ghosh, P. S. (2013). An Enigma that is South Asia: India versus the Region. Asia-Pacific Review, 20(1), 100-120, doi.org/10.1080/13439006.2013.788336

Gupta, B. S. (1986). Regional Cooperation and Development in South Asia, Vol. 1. New Delhi: South Asian Publishers.

Gupta, B. S. (1983 August 31). The Indian Doctrine, India Today, 20.

Hagerty, D. T. (1991). India's Regional Security Doctrine. Asian Survey, 31(4), 351-363, www.jstor.org/stable/2645389

Hasan, S. (2017, March 2). Urdu and Hindi are one language, says scholar', Dawn. Retrieved from https://images.dawn.com/news/1177185

Hettne, B., Inotai, A.., \& Sunkel, O (2001). Editors' Introduction. In B. Hettne, A., \& O. Sunkel (Eds.) Comparing Regionalisms: Implications for Global Development. Houndsmills: Palgrave.

Hettne, B. \& Soderbaum, F. (2000). Theorising the Rise of Regionness. New Political Economy, 5(3), 457-472, doi.org/10.1080/713687778

Hudson, H.V. (1985). The Great Divide: Britain-India-Pakistan. Karachi: Oxford University Press.

Hyat, K. (2017, October 26). Progress, identity and confusion. The News International.

Indian Council of World Affairs (no date) 'Asian Relations Conference,'; accessed on 14 January 2017 at: http://icwadelhi.info/asianrelationsconference

Kahin, G. M. (1956.) The Asian-African Conference. New York: Cornell University Press.

Kardar, S. (2017, July 17). Understanding EPEC. Dawn. Retrieved from https://www.dawn.com/news/1345741

Katzenstein, P. J. (1997). Introduction: Asian Regionalism in Comparative Perspective. In P.J. Katzenstein \& T. Shiraishi (Eds.). Network Power: Japan and Asia. Ithaca, NY: Cornell University Press.

Kaul, M. \& Chakraborty, A. (Eds.) (2016) . India's Look East to Act East Policy: Tracking the Opportunities and Challenges in the Indo-Pacific. New Delhi: Pentagon Press.

Kavic, L. J. (1967). India's Quest for Security: Defence Policies, 1947-1965. Los Angeles: University of California Press.

Kaviraj, S. (2014). A Strange Love of the Land: Identity, Poetry and Politics in the (Un)Making of South Asia. Samaj: South Asia Multidisciplinary Academic Journal, 10. 
Kodikara, S. U. (1983). Strategic Factors in Inter-State Relations in South Asia. Canberra: Strategic and Defence Studies Centre, Australian National University.

Kohli, A. (2006a). Politics of Economic Growth in India, 1980-2005: Part I: The 1980s. Economic and Political Weekly, 41(13), 1251-1259.

Kohli, A. (2006b). Politics of Economic Growth in India, 1980-2005: Part II: The 1990s and Beyond. Economic and Political Weekly, 41(14), 1361-1370.

Kumar, V. (2007). Sub-Regionalism in South Asia: A Case Study of the Bangladesh-BhutanNepal-India Motor Vehicles Agreement. Strategic Analysis, 41(1), 1-13, doi.org/10.1080/09700161.2016.1249180

Kundu, S. (2017). BIMSTEC at 20: Hopes and Apprehensions. The Institute of Defence Studies and Analysis; accessed on 12 November 2017; available at: http://www.idsa.in/idsacomments/bimstec-at-20-hopes-andapprehensions_skundu_200617

Kupchan, C. A. (1997). Regionalizing Europe's Security: The Case for a New Mitteleuropa. In E. D. Mansfield \& H.V. Milner (Eds.) The Political Economy of Regionalism (pp. 209-238). New York: Columbia University Press.

- $\quad$ Mansfield, E. D. \& Milner, H. V. (1999). The New Wave of Regionalism. International Organisation, 53(3), 589-627, https://doi.org/10.1162/002081899551002

Mishra, P. K. (1982), Toward a Framework of South Asian Regional Cooperation: Colombo to Kathmandu. Foreign Affairs Report, 31

Mohammad-Arif, A. (2014). Introduction, Imaginations and Constructions of South Asia: An Enchanting Abstraction? Samaj: South Asia Multidisciplinary Academic Journal, 10

Mohan, C. R. (2017, August 16). Undoing the economic partition. The Indian Express. Retrieved from http://indianexpress.com/article/opinion/columns/undoing-theeconomic-partition-delhi-poltical-saarc-india-pakistan-independence-day-4798513/

Mohanan, B. (1992). The Politics of Regionalism in South Asia. New Delhi: Atlantic Publishers and Distributors.

Muni, S. D., \& Jetly, R. (2010). SAARC Prospects: The Changing Dimensions. In S.D. Muni (Ed.) The Emerging Dimensions of SAARC (pp. 1-31). New Delhi: Foundation Books.

Muni, S. D. \& Muni, A. (1984). Regional Cooperation in South Asia. New Delhi: National Publishing House.

Murtaza, N. (2017, October 24). Booms and Busts. Dawn. Retrieved from https://www.dawn.com/news/1365859

Nye, J. S. (1971). Peace in Parts: Integration and Conflict in Regional Organization. New York: Little, Brown.

Paul, T.V. (Ed.) (2012). International Relations Theory and Regional Transformation. Cambridge: Cambridge University Press.

Rajendram, D. (2014). India's new Asia-Pacific strategy: Modi acts East. Lowy Institute, accessed on 3 November 2017; https://www.lowyinstitute.org/sites/default/files/indias-new-asia-pacific-strategymodi-acts-east.pdf 
Rashid, A. (2017, May 7). Economy: Boom or Bust? Dawn. Retrieved from https://www.dawn.com/news/1331654

Rudolph, L. I., \& Rudolph, S. H. (2006). The Making of US Foreign Policy for South Asia: Offshore Balancing in Historical Perspective. Economic and Political Weekly, 41(8), 703-709.

Russett, B. M. (1967). International Regions and the International System: A Study in Political Ecology. Chicago: Rand-McNally.

Rynning, S. (2017). South Asia and the Great Powers: International Relations and Regional Security. London: I.B. Tauris.

Saez, L. (2011). The South Asian Association for Regional Cooperation (SAARC): An emerging collaborative architecture. London: Palgrave Macmillan.

Singh, S., \& Cuiping, Z. (Eds.) (2017). BCIM: Economic Corridor: Chinese and Indian Perspectives. New Delhi: Adroit Publishers.

Small, A. (2015). The China-Pakistan Axis: Asia's New Geopolitics. London: C. Hurst and Co Publisher Ltd.

Sridharan, K. (2010). SAARC and Evolving Asian Regionalism. In S.D. Muni (Ed.). The Emerging Dimensions of SAARC (201-208). New Delhi: Foundation Books.

Talbot, I. (1998). Pakistan: A Modern History. New York: St Martin’s Press.

Teckchandani, J. (2016, November 19). Modi's Emerging Look West Policy. The Pioneer. Retrieved from http://www.dailypioneer.com/columnists/oped/modis-emerging-lookwest-policy.html

Tharoor, S. (2017). Inglorious Empire What the British Did to India. London: Hurst \& Company.

The Express Tribune (2016, September 39). Pakistan announces postponement of $19^{\text {th }}$ SAARC Summit. Retrieved from https://tribune.com.pk/story/1191432/pakistanannounces-postponement-19th-saarc-summit/ https://tribune.com.pk/story/1191432/pakistan-announces-postponement-19th-saarcsummit/

The Indian Express (2017, August 27). Idea of India incomplete without Jammu and Kashmir: Salman Khurshid. Retrieved from http://indianexpress.com/article/india/idea-of-india-incomplete-without-jammu-andkashmir-salman-khurshid-4816011/

Thompson, W. R. (1973). The Regional Subsystem: A Conceptual Explication and Propositional Inventory. International Studies Quarterly, 17(1), 89-117, doi.org/10.2307/3013464

Thornton, T. P. (1991). Regional Organizations in Conflict Management. Annals of the American Academy of Political and Social Science, 518 (1), 132-142.

Times of India (2017, October 26). SAARC is a 'jammed' vehicle, Foreign Secretary S Jaishankar Says. Retrieved from https://timesofindia.indiatimes.com/india/saarc-is-ajammed-vehicle-foreign-secretary-s-jaishankar-says/articleshow/61247718.cms 
World Bank (2016). The Potential for Intra-regional Trade for South Asia. 24 May; available at: https://www.worldbank.org/en/news/infographic/2016/05/24/the-potential-of-intraregional-trade-for-south-asia

Zaidi, S. A. (2014). Different Governments, Same Problems: Pakistan's Economy 19992013. In B. Chakma (Ed.). South Asia in Transition: Democracy, Political Economy and Security (pp. 109-126). London: Palgrave MacMillan.

Zaidi, S.A. (2009). South Asia? West Asia? Pakistan: Location, Identity. Economic and Political Weekly, 44(10), 36-39. 